\title{
Bioavailability of milk protein-derived bioactive peptides: a glycaemic management perspective
}

\author{
Katy Horner, Elaine Drummond and Lorraine Brennan* \\ School of Agriculture and Food Science, Institute of Food and Health and Food for Health Ireland (FHI), University College \\ Dublin, Belfield, Dublin 4, Republic of Ireland
}

\section{Abstract}

Milk protein-derived peptides have been reported to have potential benefits for reducing the risk of type 2 diabetes. However, what the active components are and whether intact peptides exert this bioactivity has received little investigation in human subjects. Furthermore, potentially useful bioactive peptides can be limited by low bioavailability. Various peptides have been identified in the gastrointestinal tract and bloodstream after milk-protein ingestion, providing valuable insights into their potential bioavailability. However, these studies are currently limited and the structure and sequence of milk peptides exerting bioactivity for glycaemic management has received little investigation in human subjects. The present article reviews the bioavailability of milk protein-derived peptides in human studies to date, and examines the evidence on milk proteins and glycaemic management, including potential mechanisms of action. Areas in need of advancement are identified. Only by establishing the bioavailability of milk protein-derived peptides, the active components and the mechanistic pathways involved can the benefits of milk proteins for the prevention or management of type 2 diabetes be fully realised in future.

\section{Key words: Bioavailability: Milk protein: Peptides: Type 2 diabetes}

\section{Introduction}

The increasing global prevalence of type 2 diabetes (T2D), a chronic health condition characterised by impaired insulin secretion and insulin resistance, highlights the urgent need for improved lifestyle intervention strategies. Milk products are available globally and have been associated with a range of health benefits, including reduced risk of $\mathrm{T} 2 \mathrm{D}^{(1,2)}$. In a recent meta-analysis, Tong et $a l^{(3)}$ reported that T2D risk could be reduced by 5 and $10 \%$ for each one serving per d of total dairy and low-fat dairy products, respectively. A separate meta-analysis of seventeen cohort studies ${ }^{(4)}$ additionally demonstrated significant inverse associations between T2D risk and intake of total dairy products, low-fat dairy products and cheese. These findings suggest that dairy products may represent a promising lifestyle intervention strategy to aid in the prevention and management of T2D. However, intervention studies are currently limited and have shown mixed results ${ }^{(5)}$. Turner et al. ${ }^{(5)}$ systematically reviewed ten randomised controlled trials, including three intervention studies that increased low-fat milk and/or yoghurt consumption per $\mathrm{d}$, six that increased the number of total dairy product serves per $\mathrm{d}$ and one that increased either daily whey or casein protein consumption. The intervention durations ranged from 1 week $^{(6)}$ to 6 months ${ }^{(7-10)}$. Four studies showed a positive effect on insulin sensitivity, one was negative and five had no effect. Methodological differences including variation in the type of dairy product consumed may be one explanation for the inconsistency in findings.

Knowledge of the properties of dairy products which may reduce T2D risk and the underlying mechanisms is important as it could assist in the development of improved prevention and management strategies for T2D, such as functional foods or nutraceuticals. Furthermore, such knowledge could assist in clarifying dietary guidelines regarding dairy product intake. Although a number of factors have been proposed and the exact mechanisms remain to be fully determined ${ }^{(11)}$, dairy protein has received recent interest as a dietary component that may aid in T2D prevention ${ }^{(12)}$. Milk protein is comprised primarily of whey and casein proteins, which constitute about 20 and $80 \%$ of the total protein fraction, respectively ${ }^{(13)}$. Whey proteins can be further subdivided into $\alpha$-lactalbumin, $\beta$-lactoglobulin, serum albumin, immunoglobulins, lactoferrin and proteose-peptone fractions, and caseins into four fractions: $\alpha-, \beta-, \gamma$ - and $\kappa$-caseins.

Milk-derived whey and casein proteins have been demonstrated to have a stimulating effect on insulin secretion in healthy, obese, pre-diabetic and T2D individuals ${ }^{(14-21)}$. Gunnerud et al. ${ }^{(17)}$ reported that whey protein affected glycaemia, insulinaemia and plasma amino acids to a glucose load in a dose-dependent manner in twelve healthy individuals.

Abbreviations: ACE, angiotension I-converting enzyme; CMP, caseinomacropeptide; DPP-4, dipeptidyl peptidase-4; GI, gastrointestinal; GIP, glucosedependent insulinotropic polypeptide; GLP-1, glucagon-like peptide-1; T2D, type 2 diabetes.

* Corresponding author: Lorraine Brennan, email lorraine.brennan@ucd.ie 
A number of studies have similarly reported beneficial effects of whey protein on insulin secretion (for a review, see Pal \& Radavelli-Bagatini $\left.{ }^{(18)}\right)$. While caseins have been less well studied, Hoefle et al. ${ }^{(19)}$ recently demonstrated that both $50 \mathrm{~g}$ sodium caseinate and $50 \mathrm{~g}$ whey protein isolate administered with maltodextrin equivalently increased insulin secretion by $96 \%$ compared with maltodextrin alone in pre-diabetic adults. The enhanced insulin secretion was accompanied by a $21 \%$ decrease in postprandial blood glucose following both protein meals. In a study of ten healthy males, a casein protein hydrolysate significantly accelerated protein digestion and absorption from the gut and enhanced postprandial insulin secretion and amino acid availability compared with its intact protein $^{(22)}$. These findings add to an increasing body of work suggesting that the composition and/or source of protein ingested and subsequent digestion and absorption pattern may have a significant impact on the postprandial metabolic response $\mathrm{e}^{(23-27)}$. The key mechanisms underlying such a response are not known but may be the result of the action of amino acids and/or bioactive peptides, either originally present in the protein or formed during gastrointestinal (GI) digestion $^{(28)}$.

The functional significance of milk protein-derived peptides for health is dependent on their bioavailability and the urgent need for an integrated approach to address the role and mechanism of action of milk protein-derived peptides in humans has been emphasised ${ }^{(29)}$. For pertinent recent reviews, see Nongonierma \& FitzGerald ${ }^{(29)}$, Boutrou et al. ${ }^{(30)}$ and Nongonierma \& FitzGerald ${ }^{(31)}$. From a glycaemic management perspective, in order to exert an effect on postprandial responses, bioactive peptides need to reach the intestine and/or bloodstream in an active form. The objective of the present review is to provide an overview of the literature on the bioavailability of milk protein-derived peptides, including studies that have identified milk protein-derived peptides in the GI tract and/or bloodstream, and to examine the evidence on potential mechanisms of action for glycaemic management, with a focus on human studies.

\section{Milk protein-derived bioactives}

Bioactive peptides are defined as specific protein fragments that have a beneficial impact on body functions and may ultimately influence health ${ }^{(32)}$. Milk protein-derived bioactive peptides are naturally present in a range of milk and dairy product-based foods ${ }^{(31)}$ and are inactive within the sequence of the parent protein but can be released during GI digestion, microbial fermentation or food processing ${ }^{(31,33,34)}$. If the structure of the bioactive peptide is known, peptides can be synthesised using a variety of methods including chemical synthesis, recombinant DNA technology and enzymic synthesis ${ }^{(35)}$.

The identification of bioactive milk peptides was first reported over 60 years ago, when it was suggested that casein-derived phosphorylated peptides enhanced vitamin D-independent bone calcification in infants with rickets ${ }^{(36)}$. Since then, knowledge of bioactive peptides has rapidly increased and peptides with various functions including opiate, anti-hypertensive, anti-thrombotic and immunomodulatory activities have been described ${ }^{(29,37-43)}$. In addition to healthenhancing properties, it should be noted that some milk proteins also include antigenic peptides that induce allergy and this has been the focus of another line of research ${ }^{(44,45)}$. Milk allergenicity can be reduced by various processing methods including hydrolysis ${ }^{(45)}$.

The hormone-like activity of bioactive peptides is based on their amino acid composition and sequence ${ }^{(46,47)}$. Bioactive peptides usually contain two to twenty amino acid residues but in some cases may consist of more than twenty amino acids ${ }^{(48)}$. For example, peptides with opioid agonistic and antagonistic activity include casoxins ( $\kappa$-casein, f(58-61); Tyr-Pro-Tyr-Tyr) and $\beta$-casomorphins (consisting of four to nine amino acid fragments of bovine $\beta$-casein $(f(60-68))^{(38,49,50)}$. Peptides that inhibit angiotension I-converting enzyme (ACE) in the cardiovascular system can exert antihypertensive effects ${ }^{(46)}$, and are one of the most studied classes of bioactive peptides ${ }^{(39)}$. Dipeptides, tripeptides and some longer-chain peptides have all been reported to have ACE-inhibitory activity ${ }^{(51,52)}$. The tripeptide Ile-Pro-Pro, for example, has been obtained from milk fermentation and has known anti-hypertensive activity ${ }^{(33)}$. Furthermore, many bioactive milk-derived peptides may have more than one functional role. For example, peptides from the sequence $60-70$ of $\beta$-casein show opioid, ACE-inhibitory and immunomodulatory activities ${ }^{(53)}$. In contrast to the aforementioned bioactivities the potential of milk-derived peptides for glycaemic management, however, have only been more recently explored and the structure and sequence of milk protein-derived peptides exerting bioactivity has received little investigation in human studies.

\section{Importance of determining bioavailability}

While promising systemic effects of both whey and casein proteins and/or their hydrolysates on blood glucose and insulin secretion in healthy, obese, pre-diabetic and T2D individuals imply a certain level of systemic availability, there is a dearth of information on the bioavailability of the bioactive peptides. These peptides must reach their target site or organ in an active form to be bioactive ${ }^{(46)}$.

\section{Gastrointestinal digestion}

Milk protein-derived peptides could produce local effects in the GI tract and/or enter intact into the bloodstream and exert systemic effects on glycaemic control. However, during the process of GI digestion, a number of factors may lead to the degradation of bioactive peptides, thereby limiting their bioavailability. To assist in understanding factors that influence the ability of a bioactive to reach its target site intact, the following paragraphs provide a brief overview of the processes involved in the GI digestion of proteins and are illustrated in Fig. 1.

To be transported intact to the target site or organ, bioactive peptides must escape degradation during digestion. In the stomach a low $\mathrm{pH}$ initiates hydrolysis, and gastric pepsin, an endopeptidase secreted by the stomach mucosa, cleaves proteins into large peptides. The generated peptides pass into the small intestine, where they are further cleaved by pancreatic 
Factors influencing bioavailability

Protein structure and composition e.g. peptide sequence, hydrolysis, molecular size, weight distribution, transport route, hyrophobicity, presence of other food compounds

Technological

e.g. oral delivery system, encapsulation strategy

Individual

e.g. gene-diet interactions, gut microbiota, diet, gastric emptyng rate proteases into free amino acids and oligopeptides. Oligopeptides are then further hydrolysed by brush-border peptidases into dipeptides, tripeptides and free amino acids. For example, the enzyme dipeptidyl peptidase-4 (DPP-4) cleaves dipeptides from the $\mathrm{N}$-terminus of oligopeptides with proline or alanine in the penultimate position ${ }^{(54)}$.

Different transport systems for the intestinal absorption of peptides have been described. Smaller peptides are transported by a specific peptide transporter (PepT1 $)^{(39,55,56)}$ located in the brush-border membrane. Oligopeptides on the other hand can be transported by transcytosis (vesicle-mediated transcellular transport) ${ }^{(55)}$ and paracellular ${ }^{(55,57)}$ pathways. The paracellular pathway is known to be a non-degradative transport route and is suggested to be the main mechanism for transport of intact peptides $^{(56)}$. Whichever the route, a variety of proteins and peptides even in small amounts could be absorbed and demonstrate physiological function ${ }^{(56)}$.

\section{Milk protein-derived peptides identified in the gastrointestinal tract and plasma}

The hypothesis that some small peptides escape degradation and are transported from the intestinal lumen into the circulation is gaining acceptance ${ }^{(58)}$. Although, this may be due in part to an increasing number of in vitro studies describing the transepithelial transport of bioactive peptides ${ }^{(58-62)}$, there is some evidence of milk protein-derived peptides identified in the GI tract and bloodstream in human subjects (for an overview, see Table 1). Indeed, 30 years ago, Svedberg et al. ${ }^{(63)}$ reported that considerable amounts of $\beta$-casomorphin- 7 , a milk opioid peptide with seven amino acids, were present in the small intestine of healthy young volunteers following the ingestion of 1 litre of bovine milk. Following these observations, Chabance et al. ${ }^{(64)}$ later examined casein peptide release and passage into the blood during digestion of milk or yoghurt in six healthy adults. Participants consumed either $500 \mathrm{ml}$ of skimmed milk or yoghurt in random order and intestinal samples were collected over $4 \mathrm{~h}$. On another three test days, blood samples were collected over $8 \mathrm{~h}$ following the consumption of $500 \mathrm{ml}$ water, skimmed milk or yoghurt. After milk or yoghurt ingestion, many peptides derived from casein, including $\alpha$-, $\beta$ - and $\kappa$-caseins, were detected in the stomach, smaller peptides were detected in the duodenum and two long peptides, the $\kappa$-caseinoglycopeptide (cCGP) f(106-117) and the $\mathrm{N}$-terminal peptide $\mathrm{f}(1-23)$ of $\alpha_{\mathrm{s} 1}$-casein were detected in the plasma. Moreover, cCGP was present for $8 \mathrm{~h}$ in the plasma after both milk or yoghurt ingestion. As cCGP was also found in the stomach for $4 \mathrm{~h}$ after milk ingestion, one explanation is that 
Table 1. Summary of studies that have identified milk protein-derived peptides in the gastrointestinal tract and/or circulation in human subjects

\begin{tabular}{|c|c|c|c|c|}
\hline Reference & $\begin{array}{l}\text { Population } \\
\text { (number and sex } \\
\text { of subjects) }\end{array}$ & Milk protein source $\dagger$ & Site studied & Peptides (fragment) identified \\
\hline $\begin{array}{l}\text { Svedberg et al. } \\
\left(_{(1985)^{(63)}}\right.\end{array}$ & Healthy (four male) & Milk (1 litre) & Duodenum & $\begin{array}{l}\beta \text {-Casein }(60-63) \text { sequence YPFP, } \beta \text {-casein }(60-65) \text { sequence YPFPGP, } \\
\beta \text {-casein }(60-66) \text { sequence YPFPGPI }\end{array}$ \\
\hline \multirow[t]{2}{*}{$\begin{array}{l}\text { Chabance et al. } \\
\text { (1998) }^{(64)}\end{array}$} & $\begin{array}{l}\text { Healthy (three male and } \\
\text { three female) }\end{array}$ & Skimmed milk $(500 \mathrm{ml})$ & Stomach, duodenum, blood & 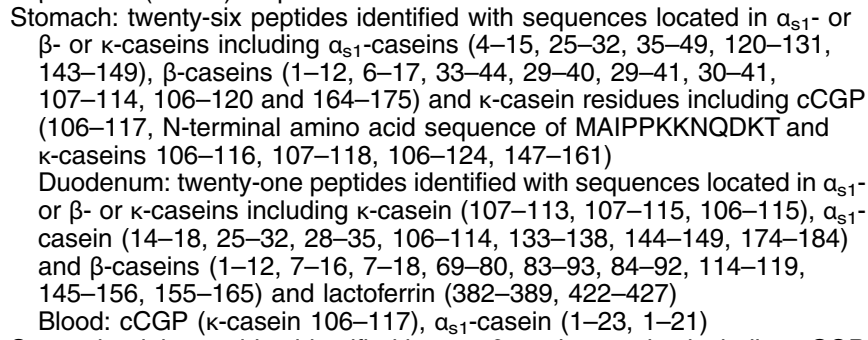 \\
\hline & & Yoghurt (500 ml) & Stomach, duodenum, blood & 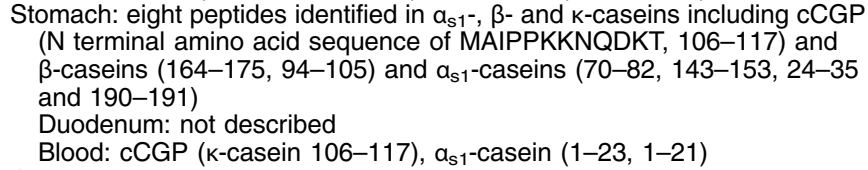 \\
\hline \multirow[t]{3}{*}{$\begin{array}{l}\text { Ledoux et al. } \\
\qquad(1999)^{(67)}\end{array}$} & Healthy $(n 6)$ & $\begin{array}{l}\text { Whey }\left(30 \mathrm{~g}^{15} \mathrm{~N} \text {-labelled) in }\right. \\
400 \mathrm{ml} \text { water }\end{array}$ & Jejunum & CMP ( $\mathrm{k}$-casein 106-169) \\
\hline & $\begin{array}{l}\text { Healthy (eight tested } \\
\text { jejunum; three tested } \\
\text { ileum) }\end{array}$ & $\begin{array}{l}\text { Casein }\left(30 \mathrm{~g}{ }^{15} \mathrm{~N} \text {-labelled }\right. \\
\text { phosphocaseinate) in } 400 \mathrm{ml} \\
\text { water }\end{array}$ & Jejunum, ileum & $\begin{array}{l}\text { Jejunum: CMP (k-casein 106-169) } \\
\text { lleum: no trace of CMP }\end{array}$ \\
\hline & Healthy $(n 4)$ & $\begin{array}{l}\text { Yoghurt }\left(300 \mathrm{~g}{ }^{15} \mathrm{~N} \text {-labelled }\right. \\
\text { yoghurt) }\end{array}$ & Jejunum & CMP (k-casein 106-169) \\
\hline $\begin{array}{l}\text { Troost et al. } \\
\quad(2001)^{(117)}\end{array}$ & $\begin{array}{l}\text { Healthy (five male } \\
\text { and seven female) }\end{array}$ & $\begin{array}{l}\text { Lactoferrin ( } 300 \mathrm{ml} \text { of } 80 \mathrm{~g} / \mathrm{l} \\
\text { maltodextrin solution in water } \\
\text { with } 4.5 \mathrm{~g} \text { bovine lactoferrin) }\end{array}$ & Stomach & Lactoferrin (fragments not identified) \\
\hline \multirow[t]{2}{*}{ Foltz et al. $(2007)^{(39)}$} & $\begin{array}{l}\text { Healthy (two male } \\
\text { and four female) }\end{array}$ & $\begin{array}{l}\text { Semi-skimmed yoghurt }(250 \mathrm{ml} \\
\text { with } 21 \mathrm{~g} \text { lactotripeptide } \\
\text { added) }\end{array}$ & $\begin{array}{l}\text { Blood (plasma concentrations } \\
\text { of ACE-inhibitory peptides } \\
\text { lle-Pro-Pro, Leu-Pro-Pro, Ala-Trp, } \\
\text { lle-Trp, Leu-Trp, Val-Tyr, lle-Tyr and } \\
\text { Phe-Tyr only were assessed) }\end{array}$ & $\begin{array}{l}\text { Ile-Pro-Pro, Leu-Pro-Pro, Ala-Trp, Ile-Trp, Leu-Trp, Val-Tyr, Ile-Tyr and } \\
\text { Phe-Tyr were all identified }\end{array}$ \\
\hline & & $\begin{array}{l}\text { Semi-skimmed yoghurt }(250 \mathrm{ml} \\
\text { with } 21 \mathrm{~g} \text { whey protein isolate } \\
\text { added) }\end{array}$ & & $\begin{array}{l}\text { Ile-Pro-Pro, Leu-Pro-Pro, Ala-Trp, Ile-Trp, Leu-Trp, Val-Tyr, Ile-Tyr and } \\
\text { Phe-Tyr were all identified }\end{array}$ \\
\hline \multirow[t]{2}{*}{$\begin{array}{l}\text { Boutrou et al. } \\
\qquad(2013)^{(68)}\end{array}$} & $\begin{array}{l}\text { Healthy (five male } \\
\text { and three female) }\end{array}$ & $\begin{array}{l}\text { Casein }\left(30 \mathrm{~g}{ }^{15} \mathrm{~N} \text {-labelled) with }\right. \\
\text { maltodextrin in } 500 \mathrm{ml} \text { water }\end{array}$ & Jejunum & $\begin{array}{l}356 \text { Peptides identified; } 218 \text { peptides from } \beta \text {-casein (the most frequent } \\
\text { being } \beta \text {-caseins (59-66, 59-68, 60-66, 108-113) and precursors for } \\
\text { tripeptides lle-Pro-Pro (74-76) and Val-Pro-Pro (84-86)), } 85 \text { from } \\
a_{\mathrm{s} 1} \text {-casein (the most frequent being } a_{\mathrm{s} 1} \text {-casein }(24-30) \text { ), twenty-nine from } \\
\mathrm{a}_{\mathrm{s} 2} \text {-casein (mostly from the } 89-122 \text { sequence) and twenty-four from } \\
\mathrm{k} \text {-casein (the most frequent from the } 52-59 \text { sequence) }\end{array}$ \\
\hline & $\begin{array}{l}\text { Healthy (five male } \\
\text { and three female) }\end{array}$ & $\begin{array}{l}\text { Whey }\left(30 \mathrm{~g}^{15} \mathrm{~N} \text {-labelled) with }\right. \\
\text { maltodextrin in } 500 \mathrm{ml} \text { water }\end{array}$ & & $\begin{array}{l}146 \text { Peptides identified; } 105 \text { from } \beta \text {-lactoglobulin (mainly from } 40-58 \text { and } \\
122-137 \text { sequences), twenty-two from a-lactalbumin (mainly from the } \\
80-90 \text { sequence), sixteen from bovine serum albumin and two from } \\
\text { lactoferrin ( } 139-145 \text { and } 607-611 \text { ) }\end{array}$ \\
\hline
\end{tabular}


$\kappa$-casein digestion resulted in a consistent flow of peptides being progressively released into the plasma. The presence of proline residues might also have protected cCGP from proteolysis ${ }^{(64)}$. More recently, in a cross-over study Foltz et al. ${ }^{(39)}$ examined the bioavailability of Ile-Pro-Pro (a whey-derived tripeptide with known high in vitro ACE-inhibitory activity ${ }^{(65)}$ ) present in a lactotripeptide-enriched yoghurt beverage compared with a whey protein isolate placebo (containing no free Ile-Pro-Pro). Plasma concentrations of Ile-Pro-Pro were elevated after both beverages, suggesting that the tripeptide may have been generated by luminal and brush-border peptidases during the placebo treatment and absorbed intact into the bloodstream.

The use of intrinsically labelled milk proteins is one method that allows for a greater understanding of the digestion and absorption of dietary milk protein-derived peptides ${ }^{(66)}$. In a formative study using ${ }^{15} \mathrm{~N}$-intrinsically labelled milk proteins, Ledoux et al. $^{(67)}$ detected milk caseinomacropeptide (CMP) in the jejunum of human subjects after ingestion of a ${ }^{15} \mathrm{~N}$-labelled casein, whey protein or yoghurt meal, indicating that CMP (a sixty-four-amino acid peptide released after $\kappa$-casein hydrolysis) resisted hydrolysis by pancreatic enzymes. This supports the earlier observations of Chabance et al. ${ }^{(64)}$ that milk-derived peptides could exert a physiological function in humans as both CMP and CMP-derived peptides have been identified as important putative bioactive sequences ${ }^{(67)}$. The presence of other peptides or presence of milk-derived peptides in the bloodstream was not examined in that study, however. Only relatively recently has an extensive characterisation of the peptides present during digestion been made possible with the use of liquid chromatography coupled with $\mathrm{MS}^{(30)}$. Using this technique in combination with ${ }^{15} \mathrm{~N}$-casein or -whey protein, Boutrou et al. ${ }^{(68)}$ detected and sequenced a total of 356 peptides following casein ingestion and 146 peptides following whey ingestion in jejunal effluents of human subjects. A large number of peptides from $\beta$ - and $\alpha_{\mathrm{s} 1}$-casein covering almost the whole sequence of both proteins were identified. However, few peptides from minor proteins such as $\kappa$-casein, lactoferrin, and serum albumin were identified, possibly due to differences in protein structure or composition ${ }^{(68)}$. The majority ( $72 \%$ ) of whey-derived peptides detected were from $\beta$-lactoglobulin and were generally of larger size (nine to fifteen amino acid residues) compared with casein (six to nine amino acid residues). $\beta$-Casein was identified as the most important precursor of peptides, including bioactive peptides such as $\beta$ casein $\mathrm{f}(60-66)$ and $\mathrm{f}(108-113)$. These peptides are known to have opioid and antihypertensive properties, respectively, and the amounts detected were suggested to be sufficiently high to exert a biological effect ${ }^{(68)}$. For example, at $2 \mathrm{~h}$ after casein ingestion, the estimated amount of $\beta$-casomorphin- 7 was $17 \mathrm{mmol} / \mathrm{l}$ and the half-maximal inhibitory concentration $\left(\mathrm{IC}_{50}\right)$ of $\beta$-casomorphin-7 for an opioid agonist activity is $3-100 \mathrm{mmol} / \mathrm{l}^{(68,69)}$. In contrast, none of the whey-derived peptides were identified as bioactive based on previous literature $^{(68)}$. A limited number of animal studies have also identified sequences of bioactive peptides present in the GI tract, with the majority deriving from casein and few from whey proteins (for a comprehensive review, see Boutrou et al. ${ }^{(30)}$ ).
Whether these peptides also reach the bloodstream in a concentration sufficient to exert a biological effect has not been established, and is particularly relevant for further study.

\section{Potential factors influencing bioavailability of milk protein-derived peptides}

An increased knowledge of the factors that influence bioavailability of bioactive peptides in humans is necessary to understand which are most important physiologically. Several studies have investigated this in in vitro experiments. However, as highlighted by Foltz et al. ${ }^{(70)}$, such an approach cannot fully characterise the poor absorption, distribution, metabolism and excretion (ADME) properties of peptides which can result in low bioavailability in humans. A limited number of studies have been undertaken in human subjects. Evidence that the level of CMP recovered after whey, casein or yoghurt ingestion depended on its transit rate in the lumen ${ }^{(67)}$ indicates that the rate of GI transit may have a significant role in determining the bioavailability of bioactive peptides. Boirie et al. ${ }^{(23)}$ have classed intact micellar casein and whey as 'slow' and 'fast' proteins, respectively, based on their digestion and absorption patterns. They found whey to produce a high, fast and transient increase of amino acids, whereas casein ingestion induced a prolonged plateau of moderately increased amino acids in healthy volunteers ${ }^{(23)}$. Casein proteins clot at low $\mathrm{pH}$, whereas whey proteins do not, which may cause casein to aggregate into a gel resulting in slower release of amino acids ${ }^{(23,71,72)}$. Hydrolysed casein on the other hand has been shown to be absorbed more rapidly than intact casein and approaches a similar rate to whey absorption ${ }^{(22,73)}$. Hydrolysis of proteins, especially casein, may consequently affect bioavailability of peptides and hence metabolic parameters ${ }^{(74)}$.

The molecular size, weight distribution and other properties of peptides, such as hydrophobicity, can determine the major transport route for peptides ${ }^{(75)}$ which in turn can also influence bioavailability. Of the two long peptides that Chabance et al. ${ }^{(64)}$ identified in the blood after milk or yoghurt ingestion, some common characteristics were identified suggesting the possibility that both peptides possess common transport pathways for intestinal absorption. Both peptides are the result of two major chymosin cleavage sites, highly hydrophilic, located on the surface of milk micelles, in part homologous, in part situated in $\beta$-turns and not rapidly destroyed by plasma proteases. Of the peptides that Boutrou et al. ${ }^{(68)}$ identified in the jejunum of human subjects they noted that most contained at least two proline residues, consistent with evidence that prolinecontaining peptides are resistant to degradation ${ }^{(76)}$. In addition to a high proline content, other characteristic features of $\beta$-casomorphins include their hydrophobic character and the presence of tyrosine on the N-terminus ${ }^{(77,78)}$. Bioavailability also appears to increase with decreasing peptide chain length ${ }^{(79)}$. For example, Foltz et al. ${ }^{(39)}$ observed that levels of dipeptides were greater than tripeptides in the plasma after whey ingestion.

Differences in whey and casein protein structure and the dairy matrix can make an impact on the bioaccessibility of 
peptides and subsequently bioavailability. Whey proteins are highly ordered globular proteins, whereas caseins have a relatively open and disordered structure which makes caseins highly susceptible to proteolysis ${ }^{(80)}$. Moreover, the presence of other food compounds could influence the susceptibility to peptidase degradation and intestinal transport ${ }^{(81)}$. For example, a substantially greater amount of carotenoids was found to be absorbed when salads were consumed with a full-fat compared with a reduced-fat salad dressing ${ }^{(82)}$. Fat slows gastric emptying and the presence of lipid products within the duodenum induces secretion of biliary and pancreatic fluids that can impact on absorption ${ }^{(81)}$. Individual differences as a result of factors such as diet, gene-diet interactions ${ }^{(83)}$, gut microbiota $^{(84)}$ or the oral mastication process ${ }^{(85)}$ could also influence the effects of dairy product intake on physiological outcomes and hence interindividual variation in bioavailability. Moreover, oral delivery systems of peptides and technological factors such as encapsulation strategies of bioactives may influence bioavailability and there is great potential for integrative studies between food scientists and drug delivery researchers in this area ${ }^{(86)}$ when bioactive sequences are identified. In the GI tract of mini-pigs, three times as many peptides were identified after ingestion of heated milk compared with rennet gels, highlighting the role that the dairy product matrix can have on peptide availability ${ }^{(87)}$. Collectively, these findings illustrate the wide range of factors (see Fig. 1) that may determine whether an ingested milkderived protein could exert a physiological effect.

\section{Mechanisms for glycaemic management}

Knowledge of the potential mechanistic pathways by which milk protein-derived peptides may enhance glycaemic management is also important to assist in enhancing their bioavailability and produce greater health benefits. Several mechanisms have been proposed whereby milk proteinderived amino acids and peptides might exert insulinotropic effects, including via direct effects on insulin secretion and indirect effects on incretin gut peptides, illustrating the potential for milk protein-derived peptides to enhance glycaemic management via multiple pathways (Fig. 1). However, whether intact peptides elicit the insulinotropic activity and the specific peptide sequences involved remains unclear.

\section{Mechanisms}

Amino acids. Several amino acids can regulate insulin secretion from pancreatic $\beta$-cells ${ }^{(88)}$, and an increase in plasma amino acids has been associated with an enhanced insulin response ${ }^{(89,90)}$. Milk proteins contain a rich source of amino acids and postprandial amino acid patterns have been consistently found to correlate with enhanced insulin responses to the ingestion of milk proteins and/or their hydrolysates in human subjects. For example, Nilsson et al. ${ }^{(89)}$ demonstrated that there was a significantly higher postprandial insulin AUC after a whey drink when compared with other animal and vegetable protein sources in twelve healthy individuals. The essential amino acids leucine, isoleucine, valine, lysine and threonine were found to show pronounced postprandial increases in plasma after the whey drink, and also showed the strongest correlation with the insulin response. Moreover, the postprandial glucose AUC was reduced by $57 \%$ after the whey drink compared with the bread reference meal. Calbet \& MacLean ${ }^{(90)}$ also observed that the insulin response was closely related to the increase in plasma amino acids, particularly leucine, isoleucine, valine, phenylalanine and arginine after a whey protein hydrolysate. In that study the whey protein hydrolysate elicited a peak insulin response four times greater than that evoked by a cows' milk solution containing complete proteins or by glucose in six healthy individuals. Others have similarly demonstrated that casein hydrolysates, compared with intact casein, show a more rapid and increased postprandial amino acid availability and increased insulin response ${ }^{(22,91)}$. These findings collectively suggest that the postprandial composition and pattern of amino acid availability could be important factors determining the insulin response to milk proteins. The mechanisms by which specific amino acids enhance insulin secretion are varied and have been comprehensively reviewed elsewhere (see Newsholme et al. ${ }^{(88,92,93)}$ ).

Incretin secretion. Milk protein-derived bioactive peptides may also have an effect on postprandial glycaemia and insulinaemia via effects on the incretin gut peptides glucagon-like peptide-1 (GLP-1) and glucose-dependent insulinotropic polypeptide (GIP). Approximately $50-70 \%$ of the insulin secretory response to an oral glucose load may be due to the stimulatory effect of gut-derived incretin peptides, although this effect is lost or greatly impaired in individuals with T2D ${ }^{(94-96)}$. Following release into the bloodstream in response to glucose or nutrient ingestion GLP-1 and GIP bind to G-protein-coupled receptors on the pancreatic $\beta$-cell membrane to stimulate the release of insulin ${ }^{(97,98)}$. However, both GLP-1 and GIP are rapidly degraded in vivo by the enzyme DPP- 4 and they have a short half-life of less than $2 \mathrm{~min}^{(99)}$. Bioactive peptides could therefore potentially act to influence postprandial incretin hormone responses by either directly stimulating an increase in GLP-1 and GIP secretion or inhibiting DPP-4 in the GI tract or bloodstream.

Increasing evidence indicates that milk-derived proteins can alter postprandial incretin hormone responses in healthy, lean, overweight/obese and T2D individuals ${ }^{(19,25,28,89,90,100-106)}$. The majority of evidence points to an enhanced GIP response to intact whey protein $(19,25,28,89,100,102)$, although there is some disparity in findings ${ }^{(107,108)}$. Similarly, much of the evidence points to an enhanced GLP-1 response to intact whey protein when compared with a variety of reference meals ${ }^{(102,104-106,109)}$ and when compared with intact casein ${ }^{(25,110,111)}$. Incretin responses to milk proteins in their hydrolysed form have been less well studied. However, in a seminal study examining postprandial responses to whey and casein proteins and their hydrolysates, Calbet \& Holst ${ }^{(73)}$ found that both whey and casein hydrolysates increased the GIP response during the first 20 min of gastric emptying compared with intact proteins in healthy individuals. Further, Bendtsen et al. ${ }^{(74)}$ more recently demonstrated that the protein form had a significant influence on the postprandial GLP-1 response pattern in healthy 
overweight and obese individuals. The GLP-1 response was enhanced at 15 min after ingestion of intact casein, but at 60 and 90 min after ingestion of a casein hydrolysate, when compared with intact whey and intact casein. These findings suggest that the protein form has a significant influence on the postprandial incretin response pattern, and that while intact casein does not appear to elicit much effect, casein hydrolysates have been shown to have some effect on incretin responses.

Dipeptidyl peptidase-4 inhibition. DPP-4-inhibitory properties of milk proteins have been increasingly demonstrated in vitro (for a comprehensive review, see Power et al. ${ }^{(80)}$ ). DPP-4 is a membrane-spanning enzyme expressed on several cell types, and is also found in a soluble circulating form ${ }^{(80)}$. Casein-derived hydrolysates, and $\beta$-caseins in particular, have generally shown a significantly higher proportion of peptide sequences with DPP-4-inhibitory activity ${ }^{(80,112)}$. However, as noted by Power et $a l .{ }^{(80)}$, if the DPP-4-inhibitory activity observed in vitro is to translate to humans it is essential that the bioavailability of these peptides is established.

Having identified several DPP-4-inhibitory peptides in goudatype cheese, Uenishi et al. ${ }^{(34)}$ performed an oral glucose test in rats to evaluate the effects of synthesised $\beta$-casein $\mathrm{f} 70-77$, the peptide with the highest DPP-4-inhibitory activity in the cheese. Administration of the synthesised peptide resulted in a significant reduction in blood glucose AUC, leading the authors to speculate that the peptide was absorbed directly into the bloodstream; however, this was not examined. Although limited, there is some evidence of an enhanced DPP-4inhibitory activity in response to whey proteins in both animal models and human subjects. In mice, Gunnarsson et al. ${ }^{(113)}$ observed that whey protein significantly enhanced both the insulin and the GIP response to glucose. They investigated whether these changes were associated with differences in DPP-4 activity and observed a significant reduction in DPP-4 activity in the duodenum - the main site of GIP synthesis, but not in the distal gut or plasma. One explanation is that protein fragments generated after whey protein digestion may serve as endogenous inhibitors of DPP-4 in the proximal gut ${ }^{(114)}$. These findings were extended by Jakubowicz et al. ${ }^{(105)}$ in a randomised cross-over clinical trial in human subjects with T2D. After a whey compared with water preload consumed before a breakfast meal, postprandial glucose levels were reduced by $28 \%$, insulin was increased by $105 \%$ and both total GLP-1 and intact GLP-1 were higher by 141 and $298 \%$, respectively. However, there were no significant differences in plasma DPP-4 activity. Although intestinal DPP-4 activity was not assessed, one explanation may be that whey protein served as an endogenous inhibitor of DPP-4 in the proximal small intestine, but not in the plasma. Alternatively, amino acids and bioactive peptides generated during whey protein GI digestion may have directly stimulated L cells to secrete GLP-1 and other incretin hormones. Further studies are needed to examine the structure and sequence of casein- and whey-derived peptides with potential DPP-4-inhibitory activity in human subjects.

Skeletal muscle glucose uptake. Bioactive peptides may also act to regulate glucose uptake in skeletal muscle. Morifuji et $a l .{ }^{(115)}$ found several dipeptides identified in whey protein hydrolysates, including Ile-Val, Leu-Val, Val-Leu, Ile-Ile, Leu-Ile, Ile-Leu and Leu-Leu, to stimulate glucose uptake in isolated skeletal muscle in vitro. Furthermore, in diabetic rats, treatment with $\beta$-casomorphin-7 lowered blood glucose and increased the expression of GLUT-4, the principal glucose transporter that mediates glucose uptake in muscle ${ }^{(116)}$. Further studies are needed to examine whether glucose uptake in skeletal muscle has a mechanistic role in the glycaemic management effects of milk protein-derived peptides in humans.

\section{Conclusions and future directions}

The current evidence base has established beneficial effects of milk proteins and/or their hydrolysates on blood glucose, insulin and incretin responses. Several mechanisms of action whereby milk proteins may exert bioactivity for glycaemic management have been proposed including enhanced amino acid availability, promotion of insulin and incretin secretion, DPP-4 inhibition and skeletal muscle glucose uptake. Milk-derived bioactive peptides may therefore offer a more diverse glycaemic management strategy compared with more targeted pharmacological approaches. However, despite this knowledge, it is currently relatively unknown as to which components of milk proteins (for example, peptide fractions, amino acids or interactions among them and gut endogenous proteins) mediate their physiological effects in humans. Moreover, while the acute effects of milk proteins are apparent, it is important for future studies to establish the long-term effects.

In order for milk protein-derived peptides to exert biological effects in humans, they must first be liberated from milk proteins by fermentation of milk, food processing and/or GI digestion. In addition, bioactive peptides must reach the small intestine and/or bloodstream intact, avoiding degradation from intestinal brush-border or serum peptidases. Various peptides have been identified in the GI tract and bloodstream after milk-protein ingestion, providing valuable insights into the potential bioavailability of milk protein-derived peptides. $\beta$-Casein-derived peptides in particular have both been identified in the GI tract in human subjects and shown to have beneficial effects for glycaemic management in vitro. However, the evidence base is limited and further work is needed to extensively characterise peptides present in the GI tract and bloodstream after milk-protein ingestion and to fully determine their functional significance in terms of glycaemic management. The availability of stable isotope labelling and recent analytical techniques now makes such extensive characterisation feasible and holds substantial potential for enhancing understanding of the structure-activity and bioavailability of milk protein-derived peptides in humans. Such knowledge is critical to improve the isolation and production of effective bioactive peptides for use in glycaemic management. Overall, while much more work is needed, milk protein-derived peptides appear to hold significant promise for future use as part of a functional food matrix or nutraceutical for glycaemic management. 


\section{Acknowledgements}

The present review was supported by Enterprise Ireland through Food for Health Ireland.

All authors contributed to and approved the final version of the manuscript.

E. D. currently works for Glanbia but has no conflicts of interest. K. H. and L. B. declare no conflicts of interest.

\section{References}

1. Kalergis M, Yinko L, Lan SS, et al. (2013) Dairy products and prevention of type 2 diabetes: implications for research and practice. Front Endocrinol (Lausanne) 4, 90.

2. Elwood PC, Givens DI, Beswick AD, et al. (2008) The survival advantage of milk and dairy consumption: an overview of evidence from cohort studies of vascular diseases, diabetes and cancer. J Am Coll Nutr 27, 723S-734S.

3. Tong X, Dong JY, Wu ZW, et al. (2011) Dairy consumption and risk of type 2 diabetes mellitus: a meta-analysis of cohort studies. Eur J Clin Nutr 65, 1027-1031.

4. Aune D, Norat T, Romundstad P, et al. (2013) Dairy products and the risk of type 2 diabetes: a systematic review and dose-response meta-analysis of cohort studies. Am J Clin Nutr 98, 1066-1083

5. Turner KM, Keogh JB \& Clifton PM (2015) Dairy consumption and insulin sensitivity: a systematic review of short- and long-term intervention studies. Nutr Metab Cardiovasc Dis 25, 3-8.

6. Hoppe C, Molgaard C, Vaag A, et al. (2004) High intakes of milk, but not meat, increase s-insulin and insulin resistance in 8-year-old boys. Eur J Clin Nutr 59, 393-398.

7. Rideout TC, Marinangeli C, Martin H, et al. (2013) Consumption of low-fat dairy foods for 6 months improves insulin resistance without adversely affecting lipids or bodyweight in healthy adults: a randomized free-living cross-over study. Nutr J 12, 56.

8. Crichton GE, Howe P, Buckley JD, et al. (2012) Dairy consumption and cardiometabolic health: outcomes of a 12-month crossover trial. Nutr Metab (Lond) 9, 19.

9. Zemel MB, Richards J, Milstead A, et al. (2005) Effects of calcium and dairy on body composition and weight loss in African-American adults. Obes Res 13, 1218-1225.

10. Wennersberg MH, Smedman A, Turpeinen AM, et al. (2009) Dairy products and metabolic effects in overweight men and women: results from a 6-mo intervention study. Am J Clin Nutr 90, 960-968.

11. Hirahatake KM, Slavin JL, Maki KC, et al. (2014) Associations between dairy foods, diabetes, and metabolic health: potential mechanisms and future directions. Metabolism $\mathbf{6 3}$, 618-627.

12. McGregor RA \& Poppitt SD (2013) Milk protein for improved metabolic health: a review of the evidence. Nutr Metab (Lond) 10, 46.

13. Jensen RG (1995) Handbook of Milk Composition. San Diego, CA: Academic Press

14. Pal S, Ellis V \& Dhaliwal S (2010) Effects of whey protein isolate on body composition, lipids, insulin and glucose in overweight and obese individuals. Br J Nutr 104, 716-723.

15. Pal S \& Ellis V (2010) The acute effects of four protein meals on insulin, glucose, appetite and energy intake in lean men. Br J Nutr 104, 1241-1248.

16. Jonker J, Wijngaarden M, Kloek J, et al. (2011) Effects of low doses of casein hydrolysate on post-challenge glucose and insulin levels. EurJ Int Med 22, 245-248.
17. Gunnerud UJ, Ostman EM \& Bjorck IME (2013) Effects of whey proteins on glycaemia and insulinaemia to an oral glucose load in healthy adults: a dose-response study. Eur $J$ Clin Nutr 67, 749-753.

18. Pal S \& Radavelli-Bagatini S (2013) The effects of whey protein on cardiometabolic risk factors. Obes Rev 14, 324-343.

19. Hoefle AS, Bangert AM, Stamfort A, et al. (2015) Metabolic responses of healthy or prediabetic adults to bovine whey protein and sodium caseinate do not differ. J Nutr $\mathbf{1 4 5}$, 467-475.

20. Power O, Hallihan A \& Jakeman P (2009) Human insulinotropic response to oral ingestion of native and hydrolysed whey protein. Amino Acids 37, 333-339.

21. Manders RJ, Hansen D, Zorenc AH, et al. (2014) Protein Co-ingestion strongly increases postprandial insulin secretion in type 2 diabetes patients. J Med Food 17, 758-763.

22. Koopman R, Crombach N, Gijsen AP, et al. (2009) Ingestion of a protein hydrolysate is accompanied by an accelerated in vivo digestion and absorption rate when compared with its intact protein. Am J Clin Nutr 90, 106-115.

23. Boirie Y, Dangin M, Gachon P, et al. (1997) Slow and fast dietary proteins differently modulate postprandial protein accretion. Proc Natl Acad Sci U S A 94, 14930-14935.

24. Mahe S, Huneau J, Marteau P, et al. (1992) Gastroileal nitrogen and electrolyte movements after bovine milk ingestion in humans. Am J Clin Nutr 56, 410-416.

25. Hall W, Millward D, Long S, et al. (2003) Casein and whey exert different effects on plasma amino acid profiles, gastrointestinal hormone secretion and appetite. Br J Nutr 89, 239-248.

26. Adibi SA \& Morse EL (1971) Intestinal transport of dipeptides in man: relative importance of hydrolysis and intact absorption. J Clin Invest 50, 2266.

27. Claessens M, Saris WH \& Van Baak MA (2008) Glucagon and insulin responses after ingestion of different amounts of intact and hydrolysed proteins. Br J Nutr 100, 61-69.

28. Frid AH, Nilsson M, Holst JJ, et al. (2005) Effect of whey on blood glucose and insulin responses to composite breakfast and lunch meals in type 2 diabetic subjects. Am J Clin Nutr 82, 69-75.

29. Nongonierma AB \& FitzGerald RJ (2015) Bioactive properties of milk proteins in humans: a review. Peptides $\mathbf{7 3}$, 20-34.

30. Boutrou R, Henry G \& Sanchez-Rivera L (2015) On the trail of milk bioactive peptides in human and animal intestinal tracts during digestion: a review. Dairy Sci Technol 95, $815-829$.

31. Nongonierma AB \& FitzGerald RJ (2015) The scientific evidence for the role of milk protein-derived bioactive peptides in humans: a review. J Funct Foods 17 , 640-656.

32. Kitts DD \& Weiler K (2003) Bioactive proteins and peptides from food sources. Applications of bioprocesses used in isolation and recovery. Curr Pharm Des 9, 1309-1323.

33. Nakamura Y, Yamamoto N, Sakai K, et al. (1995) Purification and characterization of angiotensin I-converting enzyme inhibitors from sour milk. J Dairy Sci 78, 777-783.

34. Uenishi H, Kabuki T, Seto Y, et al. (2012) Isolation and identification of casein-derived dipeptidyl-peptidase 4 (DPP-4)-inhibitory peptide LPQNIPPL from gouda-type cheese and its effect on plasma glucose in rats. Int Dairy $J$ 22, 24-30

35. Gill I, López-Fandiño R, Jorba X, et al. (1996) Biologically active peptides and enzymatic approaches to their production. Enzyme Microb Technol 18, 162-183. 
36. Mellander O (1950) The physiological importance of the casein phosphopeptide calcium salts. 2. Peroral calcium dosage of infants. Some aspects of the pathogenesis of rickets. Acta Soc Bot Pol 55, 247-255.

37. FitzGerald R \& Meisel H (2003) Milk protein hydrolysates and bioactive peptides. In Advanced Dairy Chemistry: Volume 1: Proteins, 3rd ed. pp. 675-698 [PF Fox and PLH Sweeney, editors]. Boston, London, New York, Dordrect and Moscow: Kluwer Academic andPlenum Publishers.

38. Silva SV \& Malcata FX (2005) Caseins as source of bioactive peptides. Int Dairy J 15, 1-15.

39. Foltz M, Meynen EE, Bianco V, et al. (2007) Angiotensin converting enzyme inhibitory peptides from a lactotripeptide-enriched milk beverage are absorbed intact into the circulation. J Nutr 137, 953-958.

40. Nagpal R, Behare P, Rana R, et al. (2011) Bioactive peptides derived from milk proteins and their health beneficial potentials: an update. Food Funct 2, 18-27.

41. Meisel H \& FitzGerald RJ (2000) Opioid peptides encrypted in intact milk protein sequences. Br J Nutr 84, 27-31.

42. Haque E, Chand R \& Kapila S (2008) Biofunctional properties of bioactive peptides of milk origin. Food Rev Int 25, 28-43.

43. Korhonen H \& Pihlanto A (2005) Bioactive peptides: production and functionality. Int Dairy J 16, 945-960.

44. Hochwallner H, Schulmeister U, Swoboda I, et al. (2014) Cow's milk allergy: from allergens to new forms of diagnosis, therapy and prevention. Methods 66, 22-33.

45. Tsabouri S, Douros K \& Priftis KN (2014) Cow's milk allergenicity. Endocr Metab Immune Disord Drug Targets 14, 16-26.

46. Vermeirssen V, Camp JV \& Verstraete W (2004) Bioavailability of angiotensin I converting enzyme inhibitory peptides. Br J Nutr 92, 357-366.

47. Meisel H (1997) Biochemical properties of regulatory peptides derived from milk proteins. Biopolymers 43, 119-128.

48. Erdmann K, Cheung BWY \& Schröder H (2008) The possible roles of food-derived bioactive peptides in reducing the risk of cardiovascular disease. J Nutr Biochem 19, 643-654.

49. Chiba H, Tani F \& Yoshikawa M (1989) Opioid antagonist peptides derived from $\kappa$-casein. J Dairy Res 56, 363-366.

50. Schanbacher FL, Talhouk RS, Murray FA, et al. (1998) Milkborne bioactive peptides. Int Dairy J 8, 393-403.

51. Hernández-Ledesma B, Amigo L, Recio I, et al. (2007) ACEinhibitory and radical-scavenging activity of peptides derived from $\beta$-lactoglobulin $\mathrm{f}(19-25)$. Interactions with ascorbic acid. J Agric Food Chem 55, 3392-3397.

52. Yamamoto N, Maeno M \& Takano T (1999) Purification and characterization of an antihypertensive peptide from a yogurt-like product fermented by Lactobacillus helveticus CPN4. J Dairy Sci 82, 1388-1393.

53. Meisel H (2005) Biochemical properties of peptides encrypted in bovine milk proteins. Curr Med Chem 12, 1905-1919.

54. Aertgeerts K, Ye S, Tennant MG, et al. (2004) Crystal structure of human dipeptidyl peptidase IV in complex with a decapeptide reveals details on substrate specificity and tetrahedral intermediate formation. Protein Sci 13, 412-421.

55. Shimizu M (1999) Modulation of intestinal functions by food substances. Food/Nabrung 43, 154-158.

56. Shimizu M (2004) Food-derived peptides and intestinal functions. Biofactors 21, 43-47.

57. Pappenheimer JR, Dahl CE, Karnovsky ML, et al. (1994) Intestinal absorption and excretion of octapeptides composed of D amino acids. Proc Natl Acad Sci U S A 91 , 1942-1945.
58. Regazzo D, Mollé D, Gabai G, et al. (2010) The (193-209) 17 -residues peptide of bovine $\beta$-casein is transported through Caco-2 monolayer. Mol Nutr Food Res 54, 1428-1435.

59. Vermeirssen V, Deplancke B, Tappenden K, et al. (2002) Intestinal transport of the lactokinin Ala-Leu-Pro-Met-HisIle-Arg through a Caco-2 Bbe monolayer. J Pept Sci $\mathbf{8}$, 95-100.

60. Sienkiewicz-Szłapka E, Jarmołowska B, Krawczuk S, et al. (2009) Transport of bovine milk-derived opioid peptides across a Caco-2 monolayer. Int Dairy J 19, 252-257.

61. Quirós A, Dávalos A, Lasunción MA, et al. (2008) Bioavailability of the antihypertensive peptide LHLPLP: transepithelial flux of HLPLP. Int Dairy J 18, 279-286.

62. Foltz M, Cerstiaens A, van Meensel A, et al. (2008) The angiotensin converting enzyme inhibitory tripeptides Ile-Pro-Pro and Val-Pro-Pro show increasing permeabilities with increasing physiological relevance of absorption models. Peptides 29, 1312-1320.

63. Svedberg J, de Haas J, Leimenstoll G, et al. (1985) Demonstration of $\beta$-casomorphin immunoreactive materials in in vitro digests of bovine milk and in small intestine contents after bovine milk ingestion in adult humans. Peptides $\mathbf{6}$, $825-830$.

64. Chabance B, Marteau P, Rambaud JC, et al. (1998) Casein peptide release and passage to the blood in humans during digestion of milk or yogurt. Biochimie 80, 155-165.

65. Wu J, Aluko RE \& Nakai S (2006) Structural requirements of angiotensin I-converting enzyme inhibitory peptides: quantitative structure-activity relationship study of di- and tripeptides. J Agric Food Chem 54, 732-738.

66. Mahé S, Roos N, Benamouzig R, et al. (1994) True exogenous and endogenous nitrogen fractions in the human jejunum after ingestion of small amounts of ${ }^{15} \mathrm{~N}$ labeled casein. J Nutr 124, 548-555.

67. Ledoux N, Mahe S, Dubarry M, et al. (1999) Intraluminal immunoreactive caseinomacropeptide after milk protein ingestion in humans. Nabrung 43, 196-200.

68. Boutrou R, Gaudichon C, Dupont D, et al. (2013) Sequential release of milk protein-derived bioactive peptides in the jejunum in healthy humans. Am J Clin Nutr 97, 1314-1323.

69. Yoshikawa M, Suganuma H, Takahashi M, et al. (1994) Enzymatic release of pro- $\beta$-casomorphin- 9 and $\beta$-casomorphin-9 from bovine $\beta$-casein. In Casomorphins and Related Peptides: Recent Developments, pp. 38-42 [V Brantl and $\mathrm{H}$ Teschemacher, editors]. Weinheim, Germany: VCH.

70. Foltz M, van der Pijl PC \& Duchateau GS (2010) Current in vitro testing of bioactive peptides is not valuable. J Nutr 140, 117-118.

71. Mahé S, Roos N, Benamouzig R, et al. (1996) Gastrojejunal kinetics and the digestion of $\left[{ }^{15} \mathrm{~N}\right] \beta$-lactoglobulin and casein in humans: the influence of the nature and quantity of the protein. Am J Clin Nutr 63, 546-552.

72. Morifuji M, Ishizaka M, Baba S, et al. (2010) Comparison of different sources and degrees of hydrolysis of dietary protein: effect on plasma amino acids, dipeptides, and insulin responses in human subjects. J Agric Food Chem $\mathbf{5 8}$, 8788-8797.

73. Calbet JL \& Holst J (2004) Gastric emptying, gastric secretion and enterogastrone response after administration of milk proteins or their peptide hydrolysates in humans. Eur J Nutr 43, 127-139.

74. Bendtsen LQ, Lorenzen JK, Gomes S, et al. (2014) Effects of hydrolysed casein, intact casein and intact whey protein on energy expenditure and appetite regulation: a randomised, controlled, cross-over study. Br J Nutr 112, 1412-1422. 
75. Shimizu M, Tsunogai M \& Arai S (1997) Transepithelial transport of oligopeptides in the human intestinal cell, Caco-2. Peptides 18, 681-687.

76. FitzGerald RJ \& Meisel H (2000) Milk protein-derived peptide inhibitors of angiotensin-I-converting enzyme. $\mathrm{Br} \mathrm{J}$ Nutr 84, 33-37.

77. Brantl V, Teschemacher H, Henschen A, et al. (1979) Novel opioid peptides derived from casein ( $\beta$-casomorphins). I. Isolation from bovine casein peptone. Hoppe Seylers $Z$ Physiol Chem 360, 1211-1224.

78. Teschemacher H (2003) Opioid receptor ligands derived from food proteins. Curr Pharm Des 9, 1331-1344.

79. Roberts PR, Burney J, Black KW, et al. (1998) Effect of chain length on absorption of biologically active peptides from the gastrointestinal tract. Digestion 60, 332-337.

80. Power O, Nongonierma AB, Jakeman P, et al. (2014) Food protein hydrolysates as a source of dipeptidyl peptidase IV inhibitory peptides for the management of type 2 diabetes. Proc Nutr Soc 73, 34-46.

81. Charman WN, Porter CJ, Mithani S, et al. (1997) Physicochemical and physiological mechanisms for the effects of food on drug absorption: the role of lipids and pH. J Pharm Sci 86, 269-282.

82. Brown MJ, Ferruzzi MG, Nguyen ML, et al. (2004) Carotenoid bioavailability is higher from salads ingested with full-fat than with fat-reduced salad dressings as measured with electrochemical detection. Am J Clin Nutr 80, 396-403.

83. Abdullah M, Cyr A, Labonté M-E, et al. (2014) The impact of dairy consumption on circulating cholesterol levels is modulated by common single nucleotide polymorphisms in cholesterol synthesis- and transport-related genes (1038.4). FASEB J 28, 1038.4

84. Claesson MJ, Jeffery IB, Conde S, et al. (2012) Gut microbiota composition correlates with diet and health in the elderly. Nature 488, 178-184.

85. Rémond D, Machebeuf M, Yven C, et al. (2007) Postprandial whole-body protein metabolism after a meat meal is influenced by chewing efficiency in elderly subjects. $A m$ J Clin Nutr 85, 1286-1292.

86. Brayden DJ \& Baird AW (2013) Opportunities for drugdelivery research in nutraceuticals and functional foods? Ther Deliv 4, 301-305.

87. Barbé F, Le Feunteun S, Rémond D, et al. (2014) Tracking the in vivo release of bioactive peptides in the gut during digestion: mass spectrometry peptidomic characterization of effluents collected in the gut of dairy matrix fed mini-pigs. Food Res Int 63, 147-156.

88. Newsholme P, Brennan L \& Bender K (2006) Amino acid metabolism, $\beta$-cell function, and diabetes. Diabetes $\mathbf{5 5}$, S39-S47.

89. Nilsson M, Stenberg M, Frid AH, et al. (2004) Glycemia and insulinemia in healthy subjects after lactose-equivalent meals of milk and other food proteins: the role of plasma amino acids and incretins. Am J Clin Nutr 80, 1246-1253.

90. Calbet JAL \& MacLean DA (2002) Plasma glucagon and insulin responses depend on the rate of appearance of amino acids after ingestion of different protein solutions in humans. J Nutr 132, 2174-2182.

91. Deglaire A, Fromentin C, Fouillet H, et al. (2009) Hydrolyzed dietary casein as compared with the intact protein reduces postprandial peripheral, but not whole-body, uptake of nitrogen in humans. Am J Clin Nutr 90, 1011-1022.

92. Newsholme P, Bender K, Kiely A, et al. (2007) Amino acid metabolism, insulin secretion and diabetes. Biochem Soc Trans 35, 1180-1186.
93. Newsholme P \& Krause M (2012) Nutritional regulation of insulin secretion: implications for diabetes. Clin Biochem Rev 33, 35-47.

94. Holst JJ \& Gromada J (2004) Role of incretin hormones in the regulation of insulin secretion in diabetic and nondiabetic humans. Am J Physiol Endocrinol Metab 287, E199-E206.

95. Meier JJ (2009) The contribution of incretin hormones to the pathogenesis of type 2 diabetes. Best Pract Res Clin Endocrionol Metab 23, 433-441.

96. Holst JJ, Vilsboll T \& Deacon CF (2009) The incretin system and its role in type 2 diabetes mellitus. Mol Cell Endocrinol 297, 127-136.

97. Thorens B (1992) Expression cloning of the pancreatic $\beta$ cell receptor for the gluco-incretin hormone glucagon-like peptide 1. Proc Natl Acad Sci U S A 89, 8641-8645.

98. Yabe D \& Seino Y (2011) Two incretin hormones GLP-1 and GIP: comparison of their actions in insulin secretion and $\beta$-cell preservation. Prog Biophys Mol Biol 107, 248-256.

99. Mentlein R, Gallwitz B \& Schmidt WE (1993) Dipeptidyl peptidase IV hydrolyses gastric inhibitory polypeptide, glucagon like peptide-1(7-36)amide, peptide histidine methionine and is responsible for their degradation in human serum. Eur J Biochem 214, 829-835.

100. Nilsson M, Holst JJ \& Bjorck IM (2007) Metabolic effects of amino acid mixtures and whey protein in healthy subjects: studies using glucose-equivalent drinks. Am J Clin Nutr 85, 996-1004.

101. Diepvens K, Haberer D \& Westerterp-Plantenga M (2007) Different proteins and biopeptides differently affect satiety and anorexigenic/orexigenic hormones in healthy humans. Int J Obes 32, 510-518.

102. Ma J, Stevens JE, Cukier K, et al. (2009) Effects of a protein preload on gastric emptying, glycemia, and gut hormones after a carbohydrate meal in diet-controlled type 2 diabetes. Diabetes Care 32, 1600-1602.

103. Hochstenbach-Waelen A, Westerterp-Plantenga MS, Veldhorst MAB, et al. (2009) Single-protein casein and gelatin diets affect energy expenditure similarly but substrate balance and appetite differently in adults. J Nutr 139, 2285-2292.

104. Akhavan T, Luhovyy BL, Panahi S, et al. (2014) Mechanism of action of pre-meal consumption of whey protein on glycemic control in young adults. J Nutr Biochem 25, 36-43.

105. Jakubowicz D, Froy O, Ahrén B, et al. (2014) Incretin, insulinotropic and glucose-lowering effects of whey protein pre-load in type 2 diabetes: a randomised clinical trial. Diabetologia 57, 1807-1811.

106. Chungchunlam SMS, Henare SJ, Ganesh S, et al. (2015) Dietary whey protein influences plasma satiety-related hormones and plasma amino acids in normal-weight adult women. Eur J Clin Nutr 69, 179-186.

107. Veldhorst MAB, Nieuwenhuizen AG, Hochstenbach-Waelen A, et al. (2009) Effects of complete whey-protein breakfasts versus whey without GMP-breakfasts on energy intake and satiety. Appetite 52, 388-395.

108. Holmer-Jensen J, Hartvigsen ML, Mortensen LS, et al. (2012) Acute differential effects of milk-derived dietary proteins on postprandial lipaemia in obese non-diabetic subjects. Eur $J$ Clin Nutr 66, 32-38.

109. Bowen J, Noakes M \& Clifton PM (2006) Appetite regulatory hormone responses to various dietary proteins differ by body mass index status despite similar reductions in ad libitum energy intake. J Clin Endocrinol Metab 91, 2913-2919.

110. Veldhorst MAB, Nieuwenhuizen AG, Hochstenbach-Waelen A, et al. (2009) A breakfast with $\alpha$-lactalbumin, gelatin, or 
gelatin + TRP lowers energy intake at lunch compared with a breakfast with casein, soy, whey, or whey-GMP. Clin Nutr 28, 147-155.

111. Juvonen KR, Karhunen LJ, Vuori E, et al. (2011) Structure modification of a milk protein-based model food affects postprandial intestinal peptide release and fullness in healthy young men. Br J Nutr 106, 1890-1898.

112. Lacroix IME \& Li-Chan ECY (2012) Dipeptidyl peptidase-IV inhibitory activity of dairy protein hydrolysates. Int Dairy $J$ 25, 97-102.

113. Gunnarsson P, Winzell MS, Deacon CF, et al. (2006) Glucose-induced incretin hormone release and inactivation are differently modulated by oral fat and protein in mice. Endocrinology 147, 3173-3180.
114. Drucker DJ (2006) Enhancing the action of incretin hormones: a new whey forward? Endocrinology 147, 3171-3172.

115. Morifuji M, Koga J, Kawanaka K, et al. (2009) Branchedchain amino acid-containing dipeptides, identified from whey protein hydrolysates, stimulate glucose uptake rate in L6 myotubes and isolated skeletal muscles. J Nutr Sci Vitaminol 55, 81-86.

116. Han D-N, Zhang D-H, Wang L-P, et al. (2013) Protective effect of $\beta$-casomorphin-7 on cardiomyopathy of streptozotocin-induced diabetic rats via inhibition of hyperglycemia and oxidative stress. Peptides 44, 120-126.

117. Troost FJ, Steijns J, Saris WH, et al. (2001) Gastric digestion of bovine lactoferrin in vivo in adults. J Nutr 131, 2101-2104. 